\title{
Enantioselective Iridium(I)-Catalyzed Allylation of Sodium 2-Aminobenzenethiolates
}

\section{Key words}

\section{iridium}

allylation

N,S-heterocycles

\section{Overall transformation:}
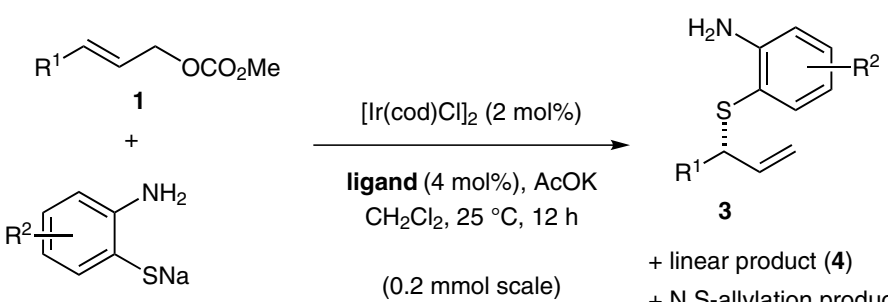

+ linear product (4)

$+\mathrm{N}, \mathrm{S}$-allylation product $(\mathbf{5})$

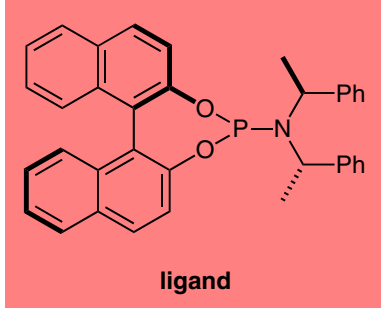

Selected substrate scope:<smiles>C=C[C@H](Sc1ccccc1N)c1ccccc1</smiles>

$83 \%$ yield (3), $96 \%$ ee $\mathbf{3} / \mathbf{4} / \mathbf{5}=\mathbf{9 6 : 4}$ trace<smiles>C=C[C@@H](Sc1ccccc1N)c1cccc(C(F)(F)F)c1</smiles>

$75 \%$ yield (3), $97 \%$ ee $\mathbf{3} / \mathbf{4} / \mathbf{5}=\mathbf{9 6 : 4 : \text { trace }}$

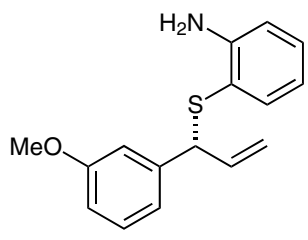

$74 \%$ yield (3), $96 \%$ ee 3/4/5 = 94:8:8:trace<smiles>C=C[C@H](Sc1ccccc1N)C(C)C</smiles>

$75 \%$ yield (3), $94 \%$ ee $\mathbf{3} / \mathbf{4} / \mathbf{5}=\mathbf{9 6 : 4 : \text { trace }}$<smiles>C=C[C@@H](Sc1ccccc1N)c1ccc(OC)cc1</smiles>

$\mathbf{3} / \mathbf{4} / \mathbf{5}=90: 10 \cdot \operatorname{trace}$<smiles>C=C[C@H](C)Sc1ccccc1N</smiles>

$54 \%$ yield (3), $94 \%$ ee $3 / 4 / 5=98: 2:$ trace<smiles>C=CC(Sc1ccccc1N)c1ccc(Br)cc1</smiles><smiles>C=CC(Sc1ccc(Cl)cc1N)c1ccc(Br)cc1</smiles>

$52 \%$ yield (3), 96\% ee $\mathbf{3} / \mathbf{4} / \mathbf{5}=\mathbf{8 5 : 1 5 : \text { trace }}$
Significance: Iridium-catalyzed enantioselective allylation has emerged as a powerful method to synthesize structurally diverse, chiral molecules. Despite much progress in the area of enantioselective carbon-sulfur bond formation using iridium, there have been no reports on the use of sodium 2-aminobenzenethiolate as a nucleophile in this class of reaction. Despite, the potential of this substrate class to encounter detrimental 'ortho-substituent effects' on stereoselectivity, Zhao accomplishes selective and highly enantioselective S-allylation.

SYNFACTS Contributors: Mark Lautens, David A. Petrone Synfacts 2013, 9(1), 0071 Published online: 17.12.2012 DOI: 10.1055/s-0032-1317762; Reg-No.: L16212SF
Comment: The authors report an iridium-catalyzed asymmetric S-allylation reaction using chiral phosphoramidite ligands. The method is highly regio- and enantioselective for a variety of aryl- and alkyl-substituted allyl carbonates. Yields range from moderate to good with excellent enantiocontrol. In most cases, the authors are able to completely inhibit bisallylation and maintain high levels of branched-to-linear selectivity. The author use the products to synthesize enantioenriched N,Sheterocycles via an $\mathrm{N}$-allylation/ring-closing metathesis sequence. 